\title{
ОСОБЛИВОСТІ ВЕДЕННЯ РЕВМАТОЛОГІЧНИХ ХВОРИХ ЗА УМОВ ПАНДЕМІЇ COVID-19: СПІВПРАЦЯ ПЕРВИННОЇ ЛАНКИ ТА РЕВМАТОЛОГА
}

\author{
О. І. Зарудна, Д. О. Зарудна \\ Тернопільський національний медичний університет \\ імені І. Я. Горбачевського МОз Украӥни
}

У статті наведено сучасні дані щодо статистичних даних, ризиків інфікування та особливостей перебігу ковідної інфекції у пацієнтів ревматологічного профілю. Висвітлено питання базисного та симптомомодифікуючого лікування аутоімунних ревматичних захворювань за умов пандеміі.

\section{MANAGEMENT PECULIARITIES OF THE RHEUMATOLOGICAL PATIENTS UNDER THE CONDITIONS OF THE COVID-19 PANDEMIC: COOPERATION BETWEEN THE PRIMARY CARE UNITS AND THE RHEUMATOLOGIST}

\author{
O. I. Zarudna, D. O. Zarudna
}

\section{Horbachevsky Ternopil National Medical University}

The article presents up-to-date statistical information, risks of infection and peculiarities of co-infection in rheumatological patients. It highlights basic and symptom-modifying treatment of autoimmune rheumatic diseases under the conditions of the Covid-19 pandemic.

...і немає більше хірургів, урологів, ортопедів,
ми лише лікарі, які раптово стали частиною
однієї команди
для боротьби з цунамі, що нас накрило.
Dr. Daniele Macchine
Бергамо, Італія, 9 березня $2020 \mathrm{p}$.

Вступ. На час підготовки статті статистика захворюваності на COVID-19 в Україні та й усьому світі в цілому $є$ невтішною. Зокрема, на тлі позитивної динаміки зниження захворюваності у деяких країнах (наприклад, Італії) спостерігається плато чи зростання захворюваності в Україні, Польщі та багатьох інших. Окрім цього, епідеміологи обґрунтовано очікують другої хвилі пандемії. Ревматологічна служба, очевидно, не знаходиться на передовій в боротьбі з COVID-19, проте змушена змінюватись на вимогу часу з метою продовження надання якісної медичної допомоги ревматологічним хворим, які становлять значну частку пацієнтів кожного сімейного лікаря. Багато ревматологічних відділень та кабінетів амбулаторного прийому хворих за умов поліклінік значно скоротили свою практику через різні при-

() О. І. Зарудна, Д. О. Зарудна, 2020 чини. Зокрема - перепрофілювання лікарень для надання допомоги хворим на COVID-19, скорочення ревматологічних ліжок із тієї ж причини, тимчасове закриття служби у зв'язку із локальними спалахами коронавірусної інфекції. Водночас ревматологи усього світу отримують безліч запитань від своїх пацієнтів, які страждають від імунозапальних та аутоімунних ревматичних захворювань, що стосуються ризику зараження COVID-19, можливості продовжувати лікування препаратами, які мають імуносупресивну дію, - глюкокортикоїдами, синтетичними базисними протизапальними препаратами (метотрексат, лефлуномід, мофетилу мікофенолат та ін.), генно-інженерними біологічними препаратами, JAK-інгібіторами, а також нестероїдними протизапальними препаратами [1]. За таких умов зростає навантаження на лікаря та медичну сестру первинної ланки медичної допомоги, 
які повинні надати пацієнту об'єктивну інформацію. Проте, якщо ще декілька місяців тому наукових даних було обмаль, то зараз уже сформульовано перелік чітких рекомендацій щодо особливостей ведення ревматологічних пацієнтів, які повинні бути донесені й до фахівців первинної ланки.
Основна частина. Перше питання, яке зазвичай цікавить пацієнтів, - це безпека, пов'язана як з рутинними життєвими обставинами, так і відвідуванням медичних установ. Для цього створено перелік нозологічних форм, асоційованих із підвищеним ризиком інфікування COVID-19 (табл. 1) [1, 2].

\section{Таблиця 1. Перелік захворювань ревматологічного профілю із підвищеним ризиком інфікування COVID-19}

\begin{tabular}{|l|c|}
\hline \multicolumn{1}{|c|}{ Нозологія, стан } & $\begin{array}{c}\text { Група ризику (ДВ - дуже високий, } \\
\text { В - високий, П - підвищений) }\end{array}$ \\
\hline $\begin{array}{l}\text { Будь-які захворювання сполучної тканини аутоімунного ґенезу та системні } \\
\text { васкуліти }\end{array}$ \\
\hline Системний червоний вовчак & В/ДВ \\
\hline Системний склероз/склеродермія & В/ДВ \\
\hline Міозит, поліміозит, дерматоміозит, антисинтетазний синдром & В \\
\hline Первинний/вторинний синдром Шегрена & В \\
\hline Перехресний синдром (оverlap-syndrome) & В/ДВ \\
\hline АНЦА-асоційовані васкуліти & В/ДВ \\
\hline Синдром Бехчета & В/ДВ \\
\hline Вузликовий поліартеріїт & В/ДВ \\
\hline ІgА-асоційований васкуліт & В/ДВ \\
\hline Кріоглобулінемія/васкуліт & В \\
\hline Синдром Когана & В \\
\hline Хвороба Стілла у дорослих & В/ДВ \\
\hline Аутозапальні синдроми & В/П \\
\hline ІgG4-залежний синдром & В/П \\
\hline Ревматоїдний артрит & В/П \\
\hline Псоріатичний артрит & В/П \\
\hline Анкілозивний спондиліт & П \\
\hline Ювенільний ідіопатичний артрит & \\
\hline Ревматична поліміалгія & \\
\hline
\end{tabular}

Дані Нью-Йоркського реєстру пацієнтів із ревматичними захворюваннями, у яких діагностовано COVID-19, свідчать, що частота госпіталізації в даній когорті становила 16 \% та не відрізнялась суттєво від такої в загальній популяції [4]. Проте, за результатами аналізу EULAR (European League Against Rheumatism) COVID-19 Database, станом на 17 серпня 2020 р. госпіталізації потребували 49 \% зареєстрованих ревматологічних пацієнтів із ковідною хворобою.

Отже, поряд із виконанням загальновідомих рекомендацій ВОО3, а саме: носіння маски, дотримання соціальної дистанції та використання дезінфекторів, певна група пацієнтів все ж повинна дотримуватись вимог самоізоляції для зменшення потенційного ризику інфікування. 3 цією метою серед хворих на ревматичні захворювання виділено групи підвищеного ризику щодо інфікування COVID-19 та тяжкого перебігу інфекції [1].
1 група - пацієнти дуже високого ризику - потребують самоізоляції на період пандемії COVID-19 та підвищених санітарно-гігієнічних заходів:

- пацієнти, які приймають глюкокортикоїди у дозі >20 мг/день (у перерахунку на преднізолон);

- пацієнти, які приймають циклофосфамід у будьякій дозі за останні 6 місяців;

- пацієнти, які приймають глюкокортикоїди у дозі 5 мг/день (у перерахунку на преднізолон) більше 4 місяців у поєднанні зі синтетичними хворобомодифікуючими препаратами;

- пацієнти, які мають одну із коморбідностей (онкологічні захворювання та приймання хіміотерапевтичних препаратів, ВІЛ-інфікування, серцево-судинні захворювання, астма та хронічне обструктивне захворювання легень, ожиріння, стан після трансплантації органів) та приймають синтетичні хворобомодифікуючі препарати; люди похилого віку та вагітні; 
- пацієнти, які мають одну із коморбідностей та приймають біологічні хворобомодифікуючі препарати.

2 група - пацієнти високого ризику - потребують самоізоляції на період пандемії COVID-19 за наявності обставин високого ризику:

- пацієнти, які мають добре контрольований перебіг захворювання (низька активність або ремісія), приймають один із синтетичних хворобомодифікуючих препаратів та не мають коморбідностей.

3 група - пацієнти помірного ризику - немає потреби в самоізоляції, необхідно дотримуватися загальних санітарно-гігієнічних норм:
- пацієнти із ремісією ревматичних захворювань, які отримують стабільні підтримувальні дози синтетичних хворобомодифікуючих препаратів.

Друге питання - приймання яких препаратів може спричинити підвищений ризик інфікування ревматологічного пацієнта? Для цього Британською асоціацією ревматологів було створено таблицю розрахунку і стратифікації ризику пацієнта залежно від призначеного лікування (табл. 2) [7].

Оцінка факторів ризику за цією таблицею відбувається так: 3 бали і більше - пацієнт підлягає у прямому перекладі даних рекомендацій екрануванню, тобто максимальному захисту та ізоляції; 2 бали -

Таблиця 2. Стратифікація ризику пацієнтів з аутоімунними ревматичними захворюваннями

\begin{tabular}{|l|c|}
\hline \multicolumn{1}{|c|}{ Фактор ризику } & Бали \\
\hline $\begin{array}{l}\text { Кортикостероїди в дозі } \geq 20 \text { mg (0,5 мг/кг) преднізолону (або еквівалент) на добу тривалістю понад } \\
4 \text { тижні }\end{array}$ & 3 \\
\hline $\begin{array}{l}\text { Кортикостероїди в дозі } \geq 5 \text { мг преднізолону, але <20 мг (чи еквівалент) на добу тривалістю понад } \\
4 \text { тижні }\end{array}$ & 2 \\
\hline Циклофосфамід у будь-якій дозі орально чи внутрішньовенно протягом останніх 6 місяців & 3 \\
\hline $\begin{array}{l}\text { Один імуносупресивний препарат - біологічний/моноклональний, чи інший імуносупресор } \\
\text { (азатіоприн, лефлуномід, метотрексат, мофетилу мікофенолат, циклоспорин, такролімус; сюди не } \\
\text { належить гідроксихлорохін чи сульфосалазин самостійно або в комбінації), або мала молекула (всі } \\
\text { інгібітори јАК (янус-кінази)) }\end{array}$ & 1 \\
\hline Два імуносупресори або більше - біологічні/моноклональні або інгібітори ЈАК & 2 \\
\hline $\begin{array}{l}\text { Один або більше факторів із перелічених: вік >70, цукровий діабет, захворювання легень, пору- } \\
\text { шення функції нирок, ішемічна хвороба серця чи гіпертензія }\end{array}$ & 1 \\
\hline Гідроксихлорохін або сульфасалазин самостійно чи в комбінації & 0 \\
\hline
\end{tabular}

необхідна самоізоляція та дотримання соціальної дистанції; 1 бал чи менше - пацієнт повинен дотримуватись соціальної дистанції.

На жаль, дана таблиця не включає інформації про характер перебігу аутоімунного ревматичного захворювання на час стратифікації ризику, проте активність хвороби врахована в рекомендаціях, поданих вище [1].

Наступне третє питання - що робити із призначеним лікуванням, чи продовжувати приймання препаратів із відомою імуносупресивною дією? Відповідь міститься в останніх рекомендаціях EULAR [5], які стверджують, що хворий на ревматичне захворювання, у якого немає підозри чи підтвердженого діагнозу COVID-19, повинен продовжувати приймання препаратів для контролю своєї хвороби, включаючи нестероїдні протизапальні препарати (НПЗП), глюкокортикостероїди (ГКС), синтетичні та біологічні хворобомодифікуючі засоби, препарати для лікування остеопорозу, анальгетики тощо. Як пацієнт, так і лікар повинні розуміти, що різка зміна дозування чи відміна препаратів для контролю за захворюванням у більшості випадків викликає загострення та виснаження імунної системи, що, в свою чергу, підвищує ризик інфікування та негативного наслідку. Отже, контрольоване захворювання - це один із факторів захисту за умов пандемії COVID-19.

Аналіз 600 випадків коронавірусної хвороби у пацієнтів із ревматичними захворюваннями з 40 різних країн світу виявив, що приймання синтетичних базисних препаратів - таких, як гідроксихлорохін чи метотрексат, - самостійно чи в комбінації з біологічними агентами (наприклад, фактор некрозу пухлин (TNF)alfa інгібіторами), чи приймання НПЗП не асоціюється з підвищенням частоти госпіталізації. А приймання TNF-alfa інгібіторів знижує ймовірність госпіталізації. Не було виявлено також жодного зв'язку між прийманням гідроксихлорохіну та ймовірністю госпіталізації, проте приймання ГКС у дозі 10 мг на добу і більше підвищує ризик ймовірної госпіталізації пацієнта [3].

Наступна рекомендація EULAR стверджує, що за наявності у хворого на ревматичне захворювання 
легких симптомів ковідної хвороби - зміна базисної терапії повинна бути обговорена в кожному конкретному випадку. Пацієнта, у якого спостерігають погіршення симптомів ковідної хвороби, повинні передати для подальшого лікування пульмонологу, терапевту чи інфекціоністу згідно з локальними рекомендаціями [5].

Чіткішими є рекомендації NICE (National Institute for Health and Care Excellence) [2] з цього приводу:

- усі пацієнти з підозрою чи підтвердженням ковідної хвороби повинні продовжувати приймання сульфасалазину чи гідроксихлорохіну, якщо вони раніше отримували його для контролю за захворюванням;

- не припиняти раптово преднізолон (або аналогічний препарат), а дотримуватись схеми, яка була призначена раніше до прийняття іншого рішення;

- парентеральне застосування ГКС можливе лише за умови високої активності захворювання та відсутності альтернативного лікування;

- лікар, який надає медичну допомогу ревматологічному пацієнту з ковідною хворобою, має усвідомлювати, що хворі, які тривало отримують ГКС на тлі активної інфекції, можуть проявляти ознаки наднирковозалозної недостатності та потребувати вищих доз ГКС, ніж пацієнти без супутнього ревматичного захворювання;

- медичний персонал, який бере участь в лікуванні ревматологічних пацієнтів, повинен пам'ятати, що приймання НПЗП, ГКС, інгібіторів інтерлейкіну-1 та інтерлейкіну-6 може привести до атипового перебігу хвороби, зокрема відсутності лихоманки та високої концентрації СРБ.

щоб отримати більше достовірних даних та корисної інформації створено EULAR COVID-19 Database та американський реєстр. Лікарі усього світу запрошені до внесення туди інформації про пацієнтів ревматологічного профілю з підтвердженою ковідною хворобою. Це дозволить зробити правильні висновки та оптимізувати ведення таких хворих за умов пандемії.

Четверте питання - які зміни в сучасній медичній практиці повинні зменшити ризики інфікування та підвищити безпеку ревматологічного пацієнта? Відпо-

\section{СПИСОК ЛІТЕРАТУРИ}

1. Актуальні рекомендації для ревматологів у зв'язку із пандемією COVID-19: ревматичні захворювання та коронавірусна інфекція COVID-19 [Електронний ресурс]. - Режим доступу : http://amnu.gov.ua/ віді теж можна знайти в рекомендаціях NICE та EULAR. Насамперед потрібно зменшити кількість особистих візитів пацієнта в лікувальний заклад, підтримувати контакт за допомогою телефону чи відеозв'язку. У деяких випадках необхідно скористатись месенджерами та електронною поштою для консультування пацієнта. Корисною може бути рекомендація хворому про замовлення необхідних ліків поштою з доставкою додому, що зменшить ризик, пов'язаний з відвідуванням аптеки. Варто збільшити час між візитами пацієнта з метою контролю призначеної терапії до 1 разу на 3 місяці, а також попросити супроводжуючих осіб не заходити в лікувальний заклад під час огляду та консультування пацієнта.

Важливим $є$ також питання про зміну способу введення деяких (наприклад, імунобіологічних) ліків із внутрішньовенного на підшкірний з метою зменшення кількості візитів до лікувального закладу. Проте останні дані свідчать про зниження ефективності лікування у разі переходу з внутрішньовенних інфузій інфліксімабу на підшкірне введення адалімумабу. Тому пацієнтам зі стабільним перебігом хвороби необхідно продовжувати призначене лікування не змінюючи шляху введення. Така корекція терапії виправдана лише за умов неможливості забезпечення подальших внутрішньовенних інфузій [6].

Висновки. 1. Усі пацієнти ревматологічного профілю в загальному повинні дотримуватись превентивних заходів, рекомендованих ВООЗ.

2. У зв'язку з особливостями функціонування імунної системи та лікування аутоімунних ревматичних захворювань усім пацієнтам, які звертаються за медичною допомогою на першому рівні, необхідно здійснити стратифікацію ризику відповідно до одного із запропонованих способів, наведених у статті, та провести роз'яснювальну роботу з метою посилення заходів безпеки пацієнта.

3. Усвідомлення факторів ризику інфікування та наслідків серед ревматологічних пацієнтів під час пандемії допоможе як медичному персоналу, так і самому пацієнту досягти оптимального менеджменту його хвороби в умовах, що склалися.

aktualni-rekomendacziyi-dlya-revmatologiv-u-zv-yazkuiz-pandemiyeyu-covid-19-revmatychni-zahvoryuvannyata-koronavirusna-infekcziya-covid-19/. 
2. COVID-19 rapid guidline: rheumatological autoimmune inflammatory and metabolic bone disorders. NICE guideline [NG167].

3. Rheumatic disease and COVID-19: initial data from the COVID-19 Global Rheumatology Alliance provider registries / M. A Gianfrancesco, K. L. Hyrich, L.Gossec [et al.] // Lancet Rheumatol. 2020. - Vol. 2. - P. 250-253.

4. COVID-19 in immune-mediated inflammatory diseases case series from New York / R. Haberman, J. Axelrad, A. Chen [et al.] // N. Engl. J. Med. - 2020. DOI: 10.1056/NEJMc2009567. [Epub ahead of print].
5. EULAR provisional recommendations for the management of rheumatic and musculoskeletal diseases in the context of SARS-CoV-2 / R. B. Landewé, P. M. Machado, F. Kroon, [et al.] // Ann. Rheum. Dis. - 2020. - Vol. 79. - P. 851-858.

6. Magro F. Inflammatory bowel disease management during the COVID-19 outbreak: the 10 do's and don'ts from the ECCO-COVID Taskforce / F. Magro, J-F. Rahier, C. Abeu // J. Crohns Colitis. - 2020.

7. Identifying rheumatic disease patients at high risk and requiring shielding during the COVID-19 pandemic / E. Price, E. MacPhie, L. Kay [et al.] // Clin. Med. (Lond). - 2020. DOI:10.7861/clinmed.2020-0160.

Отримано 26.08.20 